\title{
Moving Faster Than the Speed of Regulation: Can State-Authorized Sports Wagering Dodge a Game- Fixing Bullet Without the Help of the Feds?
}

\author{
Anthony Cabot and Keith Miller
}

\section{Introduction}

The Professional and Amateur Sports Protection Act (PASPA), was a 1992 law that, as has been well-documented, ${ }^{1}$ effectively restricted sports betting to Nevada. ${ }^{2}$ PASPA accomplished this by dictating that states could not "sponsor, operate, advertise, promote, license, or authorize by law or compact," sports wagering. ${ }^{3}$ A separate provision forbade private parties from operating stateauthorized sportsbooks. ${ }^{4}$ In 2018, the Supreme Court invalidated PASPA as a violation of the 10th Amendment to the U.S. Constitution. ${ }^{5}$ The Court held that Congress did not have the constitutional authority to tell a state how to legislate and PASPA's provision that states could not authorize sports betting dictated to state legislatures what they were permitted to do and not do. ${ }^{6}$

The Court's ruling unleashed an explosion of pent-up energy for sports betting that had been building since PASPA became effective in 1993. Since that decision, several states have authorized sports betting in one of the most rapid

See Leading Case, Tenth Amendment-Constitutional Remedies-Severability-Murphy v. National Collegiate Athletic Association, 132 Harv. L. Rev. 387, 387 (2018).

2 See 28 U.S.C. $\S \S 3701-3704$ (2018), declared unconstitutional by Murphy v. NCAA, 138 S. Ct. 1461 (2018).

3 Id. $§ 3702(1)$.

${ }^{4}$ Id. $\S 3702(2)$.

5 Murphy, 138 S. Ct. at 1485.

${ }^{6}$ Id. at 1478.

* Anthony Cabot, JD, is the Distinguished Fellow in Gaming Law in the William S. Boyd School of Law at the University of Nevada, Las Vegas. His research interests focus on examining the effectiveness of laws and regulations in achieving the public policies underlying the legalization of commercial casinos, sports wagering, and internet gaming. Email: anthony.cabot@unlv.edu

Keith Miller, LLM, JD, is the Ellis and Nelle Levitt Distinguished Professor of Law in the Drake University Law School. His research interests focus on how gambling is regulated in the United States and globally, with particular emphasis on sports wagering, internet gambling, and state lotteries. He thanks his research assistant, William Daniel, for his help with this article. Email: keith.miller@drake.edu 
expansions of a form of gambling in US history. ${ }^{7}$ Even more states are considering legislation that would permit sports betting, and the number of states legalizing and regulating sports betting will inevitably increase in 2020 and beyond. ${ }^{8}$ The controversy over sports betting has pivoted from whether states could legally offer sports betting, to whether they should legalize sports wagering, and if so, how they should go about regulating it.

This dramatic burst of energy in the states, however, has not been accompanied by similar action in Congress. Although legislation regulating sports betting at the federal level has been proposed, the initiatives have been met with indifference and little enthusiasm. ${ }^{9}$ The surge of state legislation authorizing sports betting, along with inaction in Congress, has obscured important questions regarding sports betting. Specifically, should the federal government have a role in regulating sports betting, and if so, what should that be? Are the regulatory objectives for sports betting better served by including the federal government in some way, or is it better to solely entrust the states with this mission?

This article examines the objectives of sports betting regulation and how the achievement of these objectives can be affected by the regulatory structure that is established. While federal involvement could be beneficial in regulating some aspects of sports betting, current political realities and a history of ill-advised federal legislation on sports betting make this unlikely. Nevertheless, these questions of how sports betting should be regulated, and by whom, continue to hover over the activity. Determining the proper balance of regulation between the states and the federal government is more important now than it has ever been.

\section{The Context of Sports Betting Regulation}

Before delving into the specifics of where the locus of regulation for sports betting should lie, it is essential to address two considerations that inform the regulation of sports betting. The first is the historical relationship between the federal government and the states as it relates to gambling regulation. Although widespread sports betting is new in the US, the interaction between the state and federal governments on gambling has taken place for many years, and that history informs the current debate. ${ }^{10}$ In addition, identifying the objectives of

\footnotetext{
${ }^{7}$ As of May 1, 2020, the following states have legalized sports betting and that activity is being conducted in the state: Arkansas, Colorado, Delaware, Illinois, Indiana, Iowa, Nevada, New Hampshire, New Jersey, New York, Michigan, Mississippi, Montana, Oregon, Pennsylvania, Rhode Island, and West Virginia. Legislative Tracker: Sports Betting, Legal SpoRTs Rep., https:// www.legalsportsreport.com/sportsbetting-bill-tracker/ (last updated April 7, 2020). New Mexico also offers sports betting at some of its tribal casinos through a gaming compact. Id.

${ }^{8}$ As of May 1, 2020, North Carolina, and Tennessee have legalized sports betting and are pending launch. Id. Alabama, Alaska, Arizona, California, Connecticut, Florida, Georgia, Hawaii, Kansas, Kentucky, Louisiana, Maine, Maryland, Massachusetts, Minnesota, Missouri, Nebraska, North Dakota, Ohio, South Carolina, South Dakota, Texas, Vermont, Virginia, Washington, and Wyoming have all at least introduced bills that would legalize sports betting. See id.

${ }^{9}$ See, e.g., Sports Wagering Market Integrity Act of 2018, S. 3793, 115th Cong. (2018).

${ }^{10}$ See Text accompanying notes 11-20.
} 
sports betting regulation may likewise assist policymakers in determining the structure of sports betting regulation.

\section{A. Historical Relationship Between the State and Federal Governments on Gambling Regulation}

Before Congress passed PASPA, the federal policy toward gambling was to assist states in enforcing their domestic laws prohibiting gambling. For example, in the federal Wire Act, ${ }^{11}$ Congress in 1961 deferred to the rights of individual states to regulate gambling within their borders. ${ }^{12}$ The Travel Act, ${ }^{13}$ the Wagering Paraphernalia Act, ${ }^{14}$ and the Illegal Gambling Business Act $^{15}$ are laws enacted during the 1960s and 1970s that also illustrated the supplementary role of federal gambling laws. Congress intervened and passed these laws when it became apparent that resource and jurisdictional constraints impaired the ability of states to investigate and prosecute multistate criminal organizations. ${ }^{16}$ Predicating federal offenses on a state law violation gave the federal government authority to investigate and prosecute national crime organizations.

Since the passage in 1978 of the Interstate Horseracing Act (IHA), however, federal intervention into gambling regulation has become more prevalent. ${ }^{17}$ With this law, Congress exercised control over the economics of the sport of horseracing by requiring race books to share a portion of each wager with the racetracks and the horse owners on whose racing events the race books were accepting bets. ${ }^{18}$

Congress's intervention in horseracing is relevant to sports wagering. PASPA prohibited states from developing their policy toward sports wagering on events involving humans, as the IHA did with wagering involving horses. Likewise, federal law could require sportsbooks to pay the leagues a portion of every bet using the IHA as precedent.

\footnotetext{
11 18 U.S.C. $\$ 1084$ (2018).

12 See United States v. Yaquinta, 204 F. Supp. 276, 277 (N.D. W. Va. 1962) ("The purpose of the [Wire Act] is succinctly stated in Report No. 588 of the Senate Judiciary Committee of the 87th Congress, on July 24, 1961, as 'to assist the several States in the enforcement of their laws pertaining to gambling and to aid in the suppression of organized gambling activities by restricting the use of wire communication facilities."”).

1318 U.S.C. $\S 1952$.

${ }^{14} I d . \S 1953$.

15 Id. $\S 1955$.

${ }_{16}$ See United States v. Roselli, 432 F.2d 879, 891 (9th Cir. 1970); see also United States v. Aquino, 336 F. Supp. 737, 739 (E.D. Mich. 1972).

17 15 U.S.C. $\$ \S 3001-3007$ (2018).

18 To this end, the original version of the Interstate Horseracing Act (IHA) prescribed rules for "interstate off-track wager[ing]," which Congress defined as a "legal wager placed or accepted in one State with respect to the outcome of a horserace taking place in another State." Id. § 3002(3). The legislative history of the law indicates Congress saw this revenue sharing as promoting the stability of horseracing and off-track betting in the United States. Congress envisioned an interstate pari-mutuel scheme to ensure that states would cooperate "in the acceptance of legal interstate wagering." See id. § 3001(3).
} 
PASPA and IHA are consistent in another important aspect. Neither act imposes federal regulation over the gambling activity itself. PASPA prohibited state-authorized sports wagering. The IHA sought to assure that the race books compensated the parties that created the event upon which race books offered wagering. While the decision in the Murphy v. NCAA (2018) case quashed Congress's effort to determine state policies toward sports betting, other ways to intrude on these state prerogatives may be proposed.

Even with the demise of PASPA, the debate as to whether the government should prohibit sports wagering or regulate it for the government's benefit is very much alive. ${ }^{19}$ However, the prospect of Congress revisiting this debate to remedy the constitutional infirmities that doomed PASPA and reimpose a national prohibition is small. A contributing reason is that so many states have now legalized sports wagering. Though the core debate on prohibition or regulation has shifted to the states, the role of the federal government in assisting the states, whether the state's policy is prohibition or regulation, remains an important question. ${ }^{20}$

\section{B. Identifying the Tenets and Objectives of Sports Betting Regulation}

When policymakers create regulatory structures for sports wagering, it is crucial that they identify the objectives they are seeking to achieve. At a fundamental level, there are four requirements that should be part of any government scheme to regulate sports betting. These are elements that are essential to establishing the trust of bettors and the public at large:

1. The games must be honest. ${ }^{21}$

2. The games should be fair. ${ }^{22}$

\footnotetext{
${ }^{19}$ One perspective is that government should permit sports wagering as an expression of individual freedom. Opponents counter by maintaining that sports wagering is socially and/or economically undesirable and should be banned. Between these two absolutist views is one that would permit licensed and regulated sports wagering if it would create positive economic benefits and negative economic or social consequences could be minimized. The prohibitionist model is well-illustrated by PASPA. Congress found that "[s]ports gambling is a national problem. The harms it inflicts are felt beyond the borders of those States that sanction it." Moreover, the Senate Judiciary Committee agreed with the testimony of NBA Commissioner David Stern, that " $[\mathrm{t}]$ he interstate ramifications of sports betting are a compelling reason for federal legislation." See S. Rep. No. 102-248 (1991), as reprinted in 1991 U.S.C.C.A.N. 3554.

${ }^{20}$ Whether the federal government will prohibit sports wagering or how it can assist the states with a ban on sports wagering is beyond the scope of this paper. Nevertheless, the statutory framework for assisting the states has existed since 1961, and more effective enforcement of the existing Federal Wire Act, whether in its current or updated form, provides both precedent and relief.

${ }^{21}$ The games can either be a random event or a sporting event.

${ }^{22}$ Fairness can concern: (1) whether the advantage the sportsbooks have over the bettors are reasonable; (2) ensuring that other bettors do not have an advantage because they have inside information; and (3) not allowing sportsbooks to rescind wagers after they are made without cause. Anthony N. Cabot \& Ngai Pindell, Regulating Land Based Casinos: Policies, Procedures, and ECONOMICS 37 (2014).
} 
3. Patrons' deposits and winnings must be secure.

4. Patrons have access to impartial procedures to resolve disputes. ${ }^{23}$

The interaction between the states and the federal government, however, can inform the efforts to achieve the objective of assuring the honesty of the underlying sporting event that determines the outcome of the sports wagering contest. Honesty in the context of wagering means that the underlying event that determines whether the bettor wins or loses the wager is determined by a random event in the case of a chance contest, or by fair and open competition in the case of a skill event. The antithesis of honesty is where the bettor is cheated or defrauded. Sports bettors face risk when sportsbooks are left to self-determine the honesty of sporting events upon which they accept wagers. Bettors may wager on the wrong side of a fixed competition and have no chance of winning their bet. ${ }^{24}$

Sports betting and casino wagering do share common features. Legally, all wagers are contracts; the price (amount won or lost) is honored according to the terms of the contract when the bettor and a bookmaker enter into it. The distinctive part of a wagering contract is that the promise of performance is based on a future contingent event - the outcome of the casino game or the sports competition-which is not under the control of the casino or sports book, on the one hand, or the bettor, on the other. Whether the sports book or the casino must fulfill its promise to pay the bettor is dependent on the terms of the bet and the outcome of the future contingent event, either the casino game or sporting event. ${ }^{25}$

Despite those commonalities, there is a critical difference between casino wagering and sports betting. In casino wagering contracts, the casinos and the regulators tightly control the future contingent event that determines win or loss. Assuring the honesty of the underlying event that determines the outcome of a sports wager, however, is a very different proposition. Rather than the uncertain contingent events occurring within the casino in a rigidly controlled environment, these uncertain contingent events that determine wins and losses in sports wagering do not occur in the casino or, typically, even in the jurisdiction where the casino is located. As a result, the integrity of the sporting event is largely outside the control of the casino regulators. Because neither the sportsbook nor the regulators control the honesty of the underlying contest, both the bettor and

\footnotetext{
${ }^{23}$ Id. at 112 . Factors $2-4$ have historically been the domain of state regulators and the authors do not dispute that issue.

${ }^{24}$ Despite not having any influence over the sporting event that is the contingent event in the wagering contract, sportsbooks can still cheat or defraud the patron in other ways. For example, the book could short pay bettors on wagers. In 2016, CG Technology, a sportsbook manager at seven Las Vegas casinos, was fined \$1.5 million and required to establish an escrow account to pay bettors who were shorted in the calculation of player winnings for certain types of parlay bets. Richard N. Velotta, CG Technology Agrees to Pay \$1.5 Million Fine and Pay Bettors Who Were Shorted, Las Vegas Review-Journal (July 21, 2016), https://www.reviewjournal.com/business/casinos-gaming/cg-technology-agrees-to-pay-1-5-million-fine-and-pay-bettors-who-were-shorted/. 25 Anthony Cabot \& Keith Miller, Sports Wagering in America: Policies, Economics, and ReguLATION 181 (2018).
} 
the sportsbook can be cheated, and both must rely on the efforts of others to ensure the contest's honesty. ${ }^{26}$

This has important implications for how sports betting should be regulated. Indeed, finding the correct balance between state and federal involvement may be an indispensable component of establishing a system of regulated sports betting that has the public's trust, provides revenue for governments, and promotes the integrity of the contests and the betting process. Efforts to ensure the honesty of the sporting event are consistent with the economic best interests of both the state and the sportsbook operator since both can be victims - the sportsbook directly, and the state indirectly through lower tax revenues.

\section{Possible Models for Federal and State Involvement in Regulating the Integrity of Sports Wagering}

The beginning point in constructing an effective system of regulating sports wagering is to identify possible models of regulation and assess their relative strengths and drawbacks. There are three broad paradigms that can be the basis of analysis:

1. Maintain the status quo. For most states this would effectively cede the responsibility to assure the honesty of the future contingent event that determines the outcome of wagering contracts in their jurisdiction to others, such as a private governing body that oversees the sporting event.

2. Establish multistate agreements that would use public or private enterprises to establish methods to detect and prohibit fraudulent outcomes and to cooperate on creating common standards on other matters.

3. Authorize the federal government to have primary responsibility for assuring the integrity of the underlying sporting event, and establish mandatory national standards for states and their licensees to follow, including a duty to cooperate with federal authorities.

Practically speaking, these models pose the central question of whether the involvement of the federal government in regulating sports betting would promote the integrity of that activity.

\section{Arguments Against Federal Involvement in Regulation}

\section{A. The Federal Government Has Had a Mixed Record Regarding Sports Betting Regulation}

In considering the advisability and practicability of federal legislation on sports betting, the history of two laws Congress passed on the topic is not encouraging. These laws raise concerns that future legislation on sports betting would be

${ }^{26} I d$. at 182 . 
influenced by political forces affecting the law's provisions, or the enforcement of the law by the executive branch of government.

\section{The Federal Wire Act}

Much has been written about this law that does not require repeating here. ${ }^{27}$ This 1961 statute focused on the real problem of organized crime using telephones to transact business relating to sports betting and horseracing. While legal sports betting at that time occurred only in Nevada, pari-mutuel tracks operated in many states, and the states received tax revenues from the legal wagers placed at these pari-mutuel facilities. ${ }^{28}$ When criminal elements established their illegal markets for horseracing over the phone, it not only helped to nourish the scourge of organized criminal activity in the US, it deprived the states of considerable tax revenue.

There is an overwhelming consensus that the purpose of the Wire Act was to assist states in their efforts to eradicate organized crime from these markets. ${ }^{29}$ This is the same motivation that inspired other federal anti-gambling laws in the 1960s and 1970s, which created separate federal offenses based on violations of state anti-gambling laws. ${ }^{30}$ Federal investigative and law enforcement resources played an essential role in taking on the rings of organized crime, which operated in the country without regard to state borders.

\footnotetext{
${ }^{27}$ See, e.g., Anthony Cabot, The Absence of a Comprehensive Federal Policy Toward Internet and Sports Wagering and a Proposal for Change, 17 Vill. Sports \& ENT. L.J. 271, 282 (2010) ("The Wire Act, in its entirety, reads poorly and in parts, the Act is nearly incomprehensible."); Byron La Fleur, Why Commas Matter: The Wire Act Story, LA Fleur's, https://lafleurs.com/magazine-feature/feature-magazine-feature/2019/02/13/why-commas-matter/ (last accessed April 21, 2020) (discussing how the use of commas and poor grammar have led to all of the uncertainty surrounding the Wire Act); Daniel Wallach, Did the Supreme Court Reinterpret the Wire Act to Allow Cross-Border Internet Sports Betting?, ForBes (July 8, 2018), https://www.forbes.com/sites/ danielwallach/2018/07/08/did-the-supreme-court-reinterpret-the-wire-act-to-allow-cross-borderinternet-sports-betting/\#13972a2646c5 (discussing some of the numerous provisions of the Wire Act that are unclear, especially in the context of the Internet).

${ }^{28}$ See Steven A. Riess, Sports in America from Colonial Times to the Twenty-First CentuRY: AN ENCYCLOPEDIA 459 (Routledge 2015) (stating horse racing accounted for 30 percent of the gambling dollar in the 1950s); M. Shannon Bishop, Note, And They're Off: The Legality of Interstate Pari-Mutuel Wagering and Its Impact on the Thoroughbred Horse Industry, 89 Ky. L.J. 711, 724 (2001) (noting "thirty states ha[d] been conducting interstate pari-mutuel wagering" on horse racing after the Wire Act was passed without complaint from the Justice Department); Joan S. Howland, Let's Not "Spit the Bit" in Defense of "the Law of the Horse": The Historical and Legal Development of American Thoroughbred Racing, 14 MARQ. Sports L. Rev. 473, 503 (2004) (identifying that horse racing in the 1950s and 1960s "reflected the prosperity and optimism which defined America" and that $\$ 50$ million in purses were distributed).

${ }_{29}$ See United States v. Yaquinta, 204 F. Supp. 276, 277 (N.D. W. Va 1962) ("The purpose of the [Wire Act] is succinctly stated in Report No. 588 of the Senate Judiciary Committee of the 87th Congress, on July 24, 1961, as 'to assist the several States in the enforcement of their laws pertaining to gambling and to aid in the suppression of organized gambling activities by restricting the use of wire communication facilities."').

${ }_{30}$ See 18 U.S.C. § 1952 (2018) (Travel Act); § 1953 (Wagering Paraphernalia Act); § 1955 (Illegal Gambling Business Act).
} 
While the wording of the Wire Act is a grammarian's nightmare,${ }^{31}$ it sought to assist states in protecting their legal gambling markets, a salutary objective, rather than undermining legal markets they created. Unfortunately, for the past 20 years, the meaning of the Wire Act has been a political football in the U.S. Department of Justice (DOJ).$^{32}$ Most recently, the Office of Legal Counsel (OLC) of the DOJ has opined that the law applies to all gambling activities and is not limited to sports betting. ${ }^{33}$ When combined with the holding that Internet communications are "wire communication facilit[es]" within the meaning of the Wire Act, ${ }^{34}$ any form of Internet gambling, not just sports betting, that affects interstate commerce would violate the law.

Interpreting the Wire Act to cover all forms of Internet gambling raises troubling issues on its own. But one might ask, "what does the recent OLC Opinion have to do with sports betting, which is specifically referred to in the law?" Two points are relevant here.

First, the Opinion cautions that one should not look to other federal law on the issue of "intermediate routing." 35 When data packets are transmitted online, they may come from and go to points in the same state. Because the Internet seeks to deliver the data as efficiently as possible, however, there is no guarantee that the transmission did not travel across state boundaries during its journey from a bettor to a sportsbook computer server, even when both are in the same state. ${ }^{36}$ Such a reading of the Wire Act makes an online intrastate betting market an impossibility.

\footnotetext{
${ }^{31}$ See Cabot, supra note 25; La Fleur, supra note 25.

${ }^{32}$ The interpretation of the Wire Act has changed with different administrations. The Bush Administration interpreted the Wire Act as applying to and outlawing all Internet gambling. Michelle Minton, The Original Intent of the Wire Act and Its Implications for State-Based Legalization of Internet Gambling, UNLV Center GAming Res., Sept. 2014, at 6, at https://digitalscholarship.unlv.

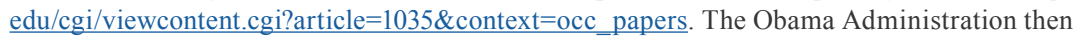
changed course in 2011 and declared the Wire Act applied only to sports betting. Office of Legal Counsel, Whether Proposals by Illinois and New York to Use the Internet and out-of-State Transaction Processors to Sell Lottery Tickets to in-State Adults Violate the Wire Act (Sept. 20, 2011). And now, the Trump Administration has flipped that understanding and said the Wire Act applies to all forms of Internet gambling. Office of Legal Counsel, Reconsidering Whether the Wire Act Applies to Non-Sports Gambling (Nov. 2, 2018). Whether this new interpretation will lead to DOJ enforcement is yet to be seen.

${ }^{33}$ Steven A. Engel, Office of Legal Counsel, U.S. Dep't of Justice Reconsidering Whether the Wire Act Applies to Non-Sports Gambling (Nov. 2, 2018), https://www.justice.gov/olc/file/1121531/ download.

${ }^{34}$ See, e.g., United States v. Lyons, 740 F.3d 702, 717 (1st Cir. 2014) (applying the Wire Act to the Internet).

${ }^{35}$ Other federal law in this context is the Unlawful Internet Gambling Enforcement Act (UIGEA). 31 U.S.C. $\$ 5362$ (2018) ("The intermediate routing of electronic data shall not determine the location or locations in which a bet or wager is initiated, received, or otherwise made.").

${ }^{36}$ See Pamela Fox, Internet Routing Protocol, Khan Academy, https://www.khanacademy.org/ computing/ap-computer-science-principles/the-internet/tcp-fault-tolerant-transmission-protocol/a/ internet-routing-protocol (last accessed April 21, 2020).
} 
While there is no specific indication the DOJ would seek to enforce this part of the Opinion, and a challenge to the Opinion is before the First Circuit Court of Appeals, ${ }^{37}$ this interpretation of the Wire Act that hamstrings rather than assists states in the enforcement of their gambling laws should give pause. Of course, a federal law on sports betting could clarify and amend the Wire Act to bring it into line with that law's clear purpose. That has been a feature of some federal proposals. ${ }^{38}$ Still, the inherently political nature of gambling issues provides no certainty that federal laws ostensibly supportive of legal markets for sports betting won't be construed in the illogical and limiting way the OLC has interpreted the Wire Act.

Additionally, congressional hearings addressing sports betting held in 2018 demonstrated a hostility toward the inevitable future of sports betting, namely, mobile sports betting. ${ }^{39}$ One legislator spoke of online gambling as being a "different beast, ${ }^{\prime \prime 0}$ and the straw man argument that there is a widespread problem with teenagers using their father's credit card, misrepresenting their identity, and gambling unimpeded on the Internet found a receptive audience. ${ }^{41}$ When the Committee chair intoned at the end of the hearings that, "I think the one thing that all of you agree on is that for Congress to do nothing is the worst possible alternative," some might disagree. ${ }^{42}$

\section{The Unlawful Internet Gambling Enforcement Act}

Despite its emergence as a marvel of technology and innovation, Internet gambling has had vociferous opponents from the time it first developed. Under President George W. Bush, the DOJ used a variety of federal laws to prosecute, harass, and intimidate online gambling operators. ${ }^{43}$ The leading case during this time was a Second Circuit decision upholding the conviction of Jay Cohen for violation of the Wire Act. ${ }^{44}$ Cohen had established an Internet-based sports betting website based in Antigua that accepted bets by phone and the Internet from bettors located in the US. ${ }^{45}$ The Court ruled that the Wire Act applied to

\footnotetext{
${ }^{37}$ N.H. Lottery Comm'n v. Barr, 386 F. Supp. 3d 132 (D.N.H. 2019), appeal filed, 1st Cir., Aug. 29, 2019.

38 See Restoration of America's Wire Act, H.R. 707, 114th Cong. (2015).

39 Eric Ramsey, Congress Tackles Sports Betting in House Subcommittee Hearing, Legal SPORTS REP. (Sept. 27, 2018), https://www.legalsportsreport.com/24476/congress-sports-betting-live-blog/.

$40 \mathrm{Id}$.

${ }^{41} I d$.

${ }^{42} I d$.

43 Primarily, the laws invoked were the Wire Act, cited previously, the Travel Act, 18 U.S.C. $\S$ 1952 (2000), and the Illegal Gambling Business Act, 18 U.S.C. $§ 1955$ (2000).

${ }^{44}$ United States v. Cohen, 260 F.3d 68 (2d Cir. 2001).

45 Id.at 70 .
} 
Cohen's operation because it was in the business of accepting bets on sports via a "wire communication facility," and the federal law specifically prohibits this. ${ }^{46}$

Even with setbacks like the Cohen case, Internet gambling continued its rapid expansion, ${ }^{47}$ suggesting to opponents that the legal tools at hand were insufficient. Beginning as early as 1996, there were several attempts to pass a federal law that would outlaw Internet gambling, typically by amending the Wire Act to expand its prohibition beyond sports betting to all forms of gambling, and making a specific reference to the Internet. ${ }^{48}$ None of these proposals came close to enactment.

By the early 2000s, opponents of Internet gambling began to take a different tack in their strategy: if Internet gambling could not be taken down directly, maybe its air supply could be cut off. The oxygen of Internet gambling was its electronic funding mechanisms such as credit and debit cards and electronic fund transfers. If the banks and credit card processors that were the vital part of Internet gambling's supply chain were incentivized not to fund these gambling transactions, Internet gambling would be suffocated. While the initial efforts to proscribe this activity failed, ${ }^{49}$ the path to success for those opposing Internet gambling appeared in 2006 with passage of the Unlawful Internet Gambling Enforcement Act (UIGEA). ${ }^{50}$

\footnotetext{
${ }^{46}$ Id. at 70-71. The case did not address the issue of whether the Wire Act applied to bets other than on sports. This is the issue that has been the subject of disagreement in the courts and within the Department of Justice. Compare In re MasterCard International, Inc, 313 F.3d 257, 263 (5th Cir. 2002) ("Because the Wire Act does not prohibit non-sports internet gambling, any debts incurred in connection with such gambling are not illegal.") with United States v. Lombardo, 639 F. Supp 2d 1271, 1281 (D. Utah 2007) ("[The Wire Act] is not confined entirely to wire communications related to sports betting or wagering.").

${ }^{47}$ One source claimed that by 2010 , Internet gambling in the U.S. would be a $\$ 25$ billion industry. Martin D. Owens, Jr., If You Can't Beat 'Em, Will They Let You Join? What American States Can Offer to Attract Internet Gambling Operators, 10 GAming L. Rev. 26, 29 (2006).

48 See a discussion of these legislative initiatives in Joseph J. McBurney, Comment, To Regulate or to Prohibit: An Analysis of the Internet Gambling Industry and the Need for a Decision on the Industry's Future in the United States, 21 ConN. J. InT'L L. 337, 348-49 (2006).

${ }^{49}$ For a discussion of the efforts to get at Internet gambling by attacking its funding, see id.; James N. Brenner, Betting on Success: Can the Unlawful Internet Gambling Enforcement Act Help the United States Achieve Its Internet Gambling Policy Goals? 30 Hastings Comm. \& Ent. L.J. 109, 121 (2007); Brant M. Leonard, Highlighting the Drawbacks of the UIGEA: Proposed Rules Reveal Heavy Burdens, 57 Drake L. Rev. 515, 524 (2009).

5031 U.S.C. $\S \S 5361-5367$ (2018).
} 
Several sources have given careful attention to the substance of UIGEA. ${ }^{51}$ In short, the law targeted both those "engaged in the business of betting or wagering," and the credit card companies, banks, and payment processors that facilitated the funding of a bettor's account with those gambling businesses. The former were prohibited from knowingly accepting credit, an electronic funds transfer, check, or similar instrument in connection with unlawful Internet gambling. ${ }^{52}$ The latter would be subject to regulations promulgated by the Federal Reserve Board and the Attorney General that required them to identify and block transactions that funded unlawful Internet gambling..$^{53}$

From its inception, UIGEA was poorly received, especially by the financial community. ${ }^{54}$ Apart from its substantive details, however, UIGEA supplies a cautionary tale when initiatives to involve the federal government in the regulation of sports betting are suggested. As has been well-documented, ${ }^{55}$ UIGEA was attached to the SAFE Port Act in a legislative maneuver that did not allow for separation of the two unrelated provisions, and, because it was presented just before Congress adjourned for its fall recess, legislators had little time to examine or debate the "must pass" proposal. ${ }^{56}$ The havoc that ensued was substantial and predictable.

It is certainly not inevitable that a federal sports betting law would be enacted with the same clandestine intrigue that was present with UIGEA. Nor is it predestined that an executive entity in the federal government would distort the

\footnotetext{
${ }^{51}$ See e.g., Kristin R. Drake, A "Royal Flush" Solution to the UIGEA Act of 2006-Congress Considers a Feasible Option to Legalizing and Regulating Online Poker in the United States, 66 CoNsumer Fin. L.Q. Rep. 211 (2012); Rotem Nicole Moran, Winner, Winner, No Chicken Dinner: An Analysis of Interactive Media Ent'mt \& Gaming Ass'n v. Att'y Gen. of the U.S. and the Unjustified Consequences of the UIGEA, 31 Loy. L.A. Ent. L. REv. 55 (2011); Brant M. Leonard, Highlighting the Drawbacks of the UIGEA: Proposed Rules Reveal Heavy Burdens, 57 DraKe L. Rev. 515 (2009); Gerd Alexander, The U.S. on Tilt: Why the Unlawful Internet Gambling Enforcement Act Is a Bad Bet, 2008 Duke L. \& Tech. Rev. 6 (2008); James N. Brenner, Betting on Success: Can the Unlawful Internet Gambling Enforcement Act Help the United States Achieve Its Internet Gambling Policy Goals?, 30 Hastings Comm. \& Ent. L.J. 109 (2008); Mattia V. Corsiglia Murawski, The Online Gambling Wager: Domestic and International Implications of the Unlawful Internet Gambling Enforcement Act of 2006, 48 SAnta Clara L. Rev. 441 (2008); Michael Blankenship, The Unlawful Internet Gambling Enforcement Act: A Bad Gambling Act? You Betcha!, 60 RutGERs L. REV. 485 (2008).

5231 U.S.C.. $\$ 5363$.

${ }^{53} I d . \S 5364$

54 See, e.g., Leonard, supra note 46, at 536-537 (discussing "widespread" concerns of financial institutions regarding "problems of enforcement" and "unanswered questions" on question of whether "e-wallets were included in the term 'designated payment system'."); Jonathan Conon, Aces and Eights: Why the Unlawful Internet Gambling Enforcement Act Resides in Dead Man's Land in Attempting to Further Curb Online Gambling and Why Expanded Criminalization Is Preferable to Legalization, 99 J. CRIM. L. \& CRIMINology 1157, 1159 (2009).

55 See, e.g., Leonard, supra note 46, at 525; I. Nelson Rose, Viewpoint: The Unlawful Internet Gambling Enforcement Act of 2006 Analyzed, 10 Gaming L. Rev. 537, 537 (2006).

56 See Leonard, supra note 46, at 525; Rose, supra note 52, at 537 ("[UIGEA] was rammed through Congress ...").
} 
law and give it an unintended and illogical interpretation. However, the history of UIGEA's enactment and the construction of the Wire Act by the DOJ's OLC are not irrelevant. They teach that sports betting legislation will require an especially high level of scrutiny so that the sea change brought about by the Murphy decision is not undone.

\section{B. The States Have Done an Excellent Job of Regulating Land- Based Casinos}

In their regulation of casino games, states have employed a number of mechanisms to promote the honesty and integrity of the games. For example, they establish and apply licensing standards for manufacturers and operators, mandate internal control requirements, establish technical standards for and require extensive testing of all games, provide for field observation of games, and demand regular audits. ${ }^{57}$

These measures have stamped out the organized crime influence and crimes like skimming that plagued the gaming industry in Nevada through the 1980s. Allegations of regulated casinos cheating a patron or offering unfair games is exceedingly rare and substantiated even less. Regulators have imposed dedicated reserve requirements on casinos that have eliminated the threat that closure, or bankruptcy, will deprive patrons of their winnings or deposits. State regulation of casino gambling has proven itself to be a system that works. Proponents of state control of sports wagering maintain that the same is true for sports betting.

\section{States Can Regulate Sports Integrity Without the Federal Government}

In addressing the risks presented by sports corruption, state gaming regulators have to adopt a much different approach than in their regulation of casino gambling. Casino regulation involves controlling a closed casino environment where regulators can create insular regulatory systems that do not interact with external communities. This, however, is not the case with sports betting. Cross border cooperation - with foreign jurisdictions as well as other states - is an essential component of monitoring sports integrity.

While cooperation agreements between state and foreign gaming regulators exist in the US, ${ }^{58}$ they are not on the scale needed to effectively regulate international sports wagering. Essential elements of a cross-border cooperation would include:

\footnotetext{
57 See Cabot \& Miller, supra note 23, at 181-82.

58 See e.g., Casino Regulatory Authority of Singapore Signs Memorandum of Understanding with Nevada Gaming Control Board, Casino Regulatory Auth. (May 26, 2011), https://www.cra.gov. $\mathrm{sg} /$ news-events/news-releases/Detail/casino-regulatory-authority-of-singapore-signs-memorandum-of-understanding-with-nevada-gaming-control-board.
} 
- Active channels for the exchange of intelligence and information related to the investigation and prosecution of manipulation of sports results at national and international levels.

- Agreeing to close access to illegal remote and land-based sportsbook operators in their jurisdiction.

- Agreeing to block the flow of funds between illegal operators and bettors.

- Agreeing to prohibit advertising by illegal operators.

- Agreeing to seize and forfeit funds related to illegal gambling and competition manipulation.

- Defining corrupt betting and competition manipulation as serious crimes.

- Agreeing to collect and preserve evidence, including electronic data related competition manipulation.

- Agreeing to require customer identification and monitoring sports bets transactions to help prevent money laundering. ${ }^{59}$

Another important feature of efforts to combat betting corruption is for state gaming regulators and their licensees to agree to share wagering information with a government-run or supervised central database to create an early warning system. The system would analyze the cumulative data using advanced algorithms to detect irregular betting patterns that might include:

- A gambler who places unusually high wagers;

- Betting volume that varied considerably from what is typical for a type or level of game;

- Betting volume that abnormally skews in favor of the underdog;

- Significant changes in odds or lines across multiple bookmakers that have no apparent explanation;

- Several new accounts placing the same wager; and

- Many of the same wagers coming from the same region or the same Internet address. ${ }^{60}$

The implementation of these measures, however, will test the resources of any state regulatory body, and done properly, might exhaust the budget of those entities.

\footnotetext{
59 See Cabot \& Miller, supra note 23, at 280-82.

${ }_{60}$ Id. at 258
} 


\section{Arguments for Federal Regulation of Sports Wagering}

\section{A. The Federal Government Can Be a Positive Force in Regulation}

Despite the lamentable examples of the Wire Act and UIGEA, the involvement of the federal government in regulating sports, and other markets, has often produced positive results.

One example is found in the way in which the federal government has regulated the securities market. The Securities Exchange Commission (SEC) was created by the Securities Exchange Act of 1934 "to restore investor confidence in our capital markets by providing investors and the markets with more reliable information and clear rules of honest dealing." ${ }^{61}$ Before the establishment of the SEC, regulating the honesty of the securities markets was left to state governments through the creation of state regulatory schemes known as "Blue Sky" laws. These proved ineffective as stock promoters complied only with the laws of the states with the least regulation or the most corruption and used that as a basis for offering the stocks on a national basis. ${ }^{62}$ While the SEC is not free from criticism for its regulation of the industry, ${ }^{63}$ few would contend that the public was better protected by a system controlled by the states, or that the SEC should be eliminated. An appropriate incorporation of a centralized system of regulation can be beneficial.

Sports wagering and stock trading share several features. Both deal with the regulation of exchanges involving contracts where the purchaser/bettor is attempting to earn profits based on a future contingent event. In both markets, the government intercedes to protect the honesty of those contracts against, among other things, fraud and insider trading.

In the sporting realm, the effectiveness of federal law enforcement to impact international sports corruption was on full display in the successful prosecution of several members of Fédération Internationale de Football Association (FIFA), the highest governing body in international soccer. In 2015, the United States Attorney General indicted 14 people for wire fraud, racketeering, and money laundering after a Federal Bureau of Investigation (FBI) and the Internal Revenue

\footnotetext{
${ }^{61} 15$ U.S.C. § 78(a) (2018); see also What We Do, U.S. SEC. \& Exch. Comm'N, https://www.sec.gov/ Article/whatwedo.html (last visited April 30, 2020).

${ }^{62}$ See Mark J. Astarita, Introduction to State Securities (Blue Sky) Laws, SEC Law, http://www. seclaw.com/introduction-to-state-securities-laws/ (last visited April 30, 2020). States were unwilling to concede power to regulate the securities markets until after the stock market crash of 1929. While the SEC has faced criticism for both overregulation and under regulation, no serious discussion exists that it is not a better system than what previously existed under state control, or that it should be dissolved. Ultimately, a centralized system has significant advantages.

${ }^{63}$ See e.g., Jonathan N. Eisenberg, Recent Criticism of the SEC: Fair or Unfair?, Harv. Law Sch. Forum on Corp. Governance (May 25, 2016), https://corpgov.law.harvard.edu/2016/05/25/ recent-criticism-of-the-sec-fair-or-unfair/ (addressing criticisms of the SEC's alleged lack of an enforcement program, among other things).
} 
Service Criminal Investigation Division probe. ${ }^{64}$ The 47 -count complaint dealt with corruption and bribery related to several matters including the commercialization of the media and marketing rights, host sites, and leadership elections. ${ }^{65}$

The FBI investigation originated in its Eurasian organized crime unit when rumors emerged that Russia might be paying bribes to host the World Cup. ${ }^{66}$ This led to the discovery of the financial status of FIFA leadership that indicated lifestyles beyond what would be expected and a system that was primed for bribery related to broadcasting, marketing, and other fees. ${ }^{67}$ The FBI then involved the Internal Revenue Service to assist in tracking funds through the international financial system. ${ }^{68}$ In addition, the FBI received the legal support of the United States Department of Justice to, among other things, get a cooperative agreement from one of the main targets necessary to unravel the depth of the corruption. ${ }^{69}$

\section{B. Ceding Total Responsibility to States for the Integrity of the Underlying Games is III-Advised}

The ability of state gaming regulators or even state prosecutors to take effective action to police the integrity of international sports is limited. Increasingly, contest integrity, like Internet gambling itself, has become a global issue. States have limited jurisdiction to prosecute violators who operate internationally. ${ }^{70}$ In the Internet gambling space, the federal government is better able to prosecute violators and enforce steps to block illegal sites, prohibit advertising for illegal sites, and work with financial institutions to stop the flow of funds between illegal operators and bettors. As early as 1995, then Florida Attorney General Bob Butterworth conceded that "evolving technology appears to be outstripping the ability of government to regulate gambling activities on the Internet and of law enforcement to enforce such regulations. Thus, resolution of these matters must be addressed at the national, if not international level." ${ }^{71}$ In a letter to the National Gambling Impact Study Commission, the National Association of Attorney Generals took the "unusual position" that state regulation of Internet gambling "would be ineffective." 72

\footnotetext{
${ }^{64}$ Nine FIFA Officials and Five Corporate Executives Indicted for Racketeering Conspiracy and Corruption, DeP'T of JusticE (May 27, 2015), https://www.justice.gov/opa/pr/nine-fifa-officials-and-five-corporate-executives-indicted-racketeering-conspiracy-and.

${ }^{65} \mathrm{Id}$.

${ }^{66}$ Shaun Assael \& Brett Forrest, The FBI vs. FIFA, ESPN, The MAgazine (Feb. 26, 2016), http:// www.espn.com/espn/feature/story//id/14767250/the-exclusive-story-how-feds-took-fifi.

${ }^{67} \mathrm{Id}$.

${ }^{68} \mathrm{Id}$.

69 Id.

${ }^{70}$ Thomas James Friedrich. Internet Casino Gambling: The Nightmare of Lawmaking, Jurisdiction, Enforcement \& the Dangers of Prohibition, 11 CommLaw Conspectus 369 (2003).

71 Florida Attorneys General's Office Formal Opinion. AGO 95-70 (Oct. 18, 1995).

72 Nat'l Gambling Impact Study Comm'n, Final Report, 5-9 (1999), available at https://govinfo. library.unt.edu/ngisc/reports/5.pdf.
} 
Increasingly, monitoring the integrity of the underlying contest requires the type of international cooperation that unraveled the FIFA corruption case. The need for global enforcement efforts is a function of the international nature of many cases of sports corruption. For example, in 2006, an Asian corruptor associated with a betting syndicate enabled the fixing of two games with the participation of members of the Ghana national team in matches against Italy and Brazil. In the latter, Ghana players allegedly allowed Brazil to score three goals so the corruptors collected on wagers that Brazil would win by more than two goals. ${ }^{73}$ A significant issue plaguing soccer is that many games played at the international level feature players with vastly disparate earnings. Players from developing countries, like Ghana, are much more receptive to bribes than their better-paid European counterparts. The bribe to the Ghana captain in the 2006 World Cup scandal was a mere $\$ 20,000$, which was then distributed to other players. ${ }^{74}$

Likewise, in 2009, German police uncovered a scheme of competition manipulation across multiple European countries known as the Bochum Competition Manipulation Scandal. The trail of that corruption illustrates the international web of the corrupt influencers. Police suspected that the criminal network involved more 200 people, and that more than 300 soccer matches in nine countries-Germany, Belgium, Switzerland, Turkey, Slovenia, Hungary, Croatia, Austria, and Bosnia-were fixed. Singapore-based financers backed by Chinese organized crime paid bribes of up to 100,000 Euros and made wagers in the millions of Euros. ${ }^{75}$ Four years later, an Asian crime syndicate, working with European criminal networks, fixed more than 680 matches over three years in 15 countries, involving 425 match officials, club officials, players, and criminals under suspicion. ${ }^{76}$

While the major American professional sports have been relatively free of sports-wagering corruption, several instances raise the question of integrity of the underlying games in both baseball (Houston Astros) ${ }^{77}$ and football (New

\footnotetext{
${ }^{73}$ Katarzyna Kordas, Dropping the Ball: How Can FIFA Address the Match-Fixing Problem Facing Professional Football, 23 Sports L.J. 107, 114 (2016).

${ }^{74}$ Declan Hill, Match-Fixing: How 2006 World Cup Fell Prey to Organized Crime, TELEGRAPH (Oct. 25, 2008), http://www.telegraph.co.uk/sport/football/3260610/Match-fixing-How-2006World-Cup-fell-prey-to-organised-crime-Football.html.

75 International Olympic Committee \& Interpol, Handbook on Protecting Sport from Competition Manipulation (May 2016), https://stillmed.olympic.org/media/Document\%20Library/OlympicOrg/IOC/What-We-Do/Protecting-Clean-Athletes/Betting/Education-Awareness-raising/Interpol-IOC-Handbook-on-Protecting-Sport-from-Competition-Manipulation.pdf [hereinafter IOC].

76 Sara Hefny, Europol Investigation of Match Fixing in Soccer Reveals Widespread Corruption, 29 InT'L ENFORCEMENT L. REP. 117 (2013).

77 The American baseball team the Houston Astros was found to have cheated in many home games by using an elaborate system to intercept the catcher's physical communications to the pitcher as to the type of pitch to be thrown. Neil Vigdor, The Houston Astros Cheating Scandal Explained, N.Y. Times (Feb. 28, 2020), https://www.nytimes.com/article/astros-cheating.html. The scheme involved using a camera fixated on the catcher's signs, a monitor with a live feed in the near the dugout, and by banging on garbage cans close enough to relay the stolen communications to the batter before the pitcher threw it.
} 
England Patriots).$^{78}$ Despite the potential impact on the outcome of games and championships, no state gaming regulator uncovered these corrupt actions, and wagers on the questionable sporting events stood as determined by the final scores. In fact, it is questionable whether states would have had any jurisdiction over the perpetrators.

A central national body that is the point of contact for intelligence and data gathering can provide the national and global expertise necessary to investigate and prosecute threats to sports integrity. A state regulatory agency typically would not have the experience, knowledge base, resources, or jurisdiction to investigate and prosecute international sports corruption.

Unless regulators have the means and resources necessary to detect this corruption, they are not upholding the first tenet of proper gaming regulation, namely, that the games are honest. This stands in stark contrast to the importance that most regulated jurisdictions place on assuring the honesty of casino games. By not being able to ensure the fundamental honesty of the underlying contingent event that is the heart of the gambling contract, the government will have to acknowledge that some persons making sports wagers could and, in some instances, will be the victim of fraud by competition manipulation.

Likewise, states are at a disadvantage in developing laws and regulations that would curb insiders from acting on information not available to the betting public. While states could share information on suspected betting irregularities by insiders, a centralized regulatory system would likely be more effective in detecting such activity. This has been one of the strengths of the way securities are regulated at the federal level. ${ }^{79}$

\footnotetext{
${ }^{78}$ In an American professional football scandal called "Deflategate," the controversy involved altered equipment. Tom Brady, the New England Patriots' star quarterback, was alleged to have been aware that footballs used by the Patriots' offense in a 2015 playoff game were deflated to a level below the air pressure required by league rules. Brady allegedly preferred this because it gave him a better grip on the softer ball and made his passes more catchable, particularly in cold or rainy weather. Don Van Natta Jr. \& Seth Wickersham, Spygate to Deflategate: Inside What Split the NFL and Patriots Apart, ESPN (Sept. 7, 2015), http://www.espn.com/espn/otl/story/ I id/13533995/split-nfl-new-england-patriots-apart; Tony Manfred, Why Using Deflated Footballs Gave the Patriots A Huge Advantage, Bus. InsIDER (Jan. 21, 2015), http://www.businessinsider. com/advantage-of-deflated-footballs-2015-1. The League imposed a four-game suspension on the quarterback because he failed to cooperate by destroying his cellphone. Id.

79 The United States Government regulates securities primarily through the Securities Act of 1933. Securities Act of 1933, Pub. L. No. 73-22, 48 Stat. 74. The Securities Act has two basic objectives: (1) "[R]equire that investors receive financial and other significant information concerning securities being offered for public sale;" and (2) "[P]rohibit deceit misrepresentations, and other fraud in the sale of securities." See What We Do, supra note 54. States also have authority to regulate securities within their state. These laws, known as "blue sky laws," are often modeled on their federal analog. Because of the overlapping and duplicative nature of many of these state laws, some have called for an entire, or field preemption, of state regulation of securities. See Rutherford Campbell Jr., The Case for Federal Pre-Emption of State Blue Sky Laws, The Heritage Foundation (Feb. 28, 2017), http://www.heritage.org/markets-and-finance/report/the-case-federalpre-emption-state-blue-sky-laws.
} 
The federal government also can adopt a comprehensive (and uniform) definition of what constitutes competition manipulation and other corrupt acts. This would include prescribing the criminal liability for engaging in competition manipulation or other corrupt acts, and penalties such as fines, prison, and asset forfeiture. Moreover, it can work with foreign governments to establish more uniform laws internationally, much as it does with anti-money laundering. ${ }^{80}$ Before the enactment of the Bank Secrecy Act, ${ }^{81}$ which established the basis for modern anti-money laundering laws ${ }^{82}$ states regulated money laundering crimes. Part of the impetus for the Bank Secrecy Act was the recognition that federal regulation of this global criminal activity was necessary because of the limitations that states faced with resources and jurisdiction..$^{83} \mathrm{~A}$ similar justification would underlie federal involvement with sports betting.

The consistency of standards and enforcement from a federal system of regulation would implicate several aspects of a sports betting structure and help to serve important public policy objectives. For example, "Know Your Customer" (KYC) standards should be imposed on sportsbooks for all substantial bettors and should include obtaining and reviewing basic government identity information, and reviewing the bettor identification against lists of people who present sports integrity risks (e.g., players, officials, referees, convicted corruptors). Likewise, requirements that licensed gambling operators file suspicious activity reports regarding potential criminal activities by patrons should be expanded to require gaming operators to report to the government irregular gambling patterns or other suspicious activities related to sports corruption to the government.

\section{Current Proposals for Federal Involvement in Regulating Sports Betting}

In the aftermath of the Murphy decision, proposals for a federal presence in sports betting regulation have been presented to Congress. ${ }^{84}$ The initial bill was put forward in December 2018 by Senators Orrin Hatch and Chuck Schumer. Hatch was a co-author of PASPA in 1992 and was a champion of the view that sports betting needed federal oversight. ${ }^{85}$ When he retired and left office in January 2019, the role of co-sponsor in a new session of Congress was taken up

\footnotetext{
${ }_{80}$ See John T. Holden, Regulating Sports Wagering, 105 Iowa L. Rev. 575, 616 (2019).

8131 U.S.C. $\$ \S 5311-5332$ (2018)

${ }^{82}$ Anne Eberhardt, History and Enforcement of Anti-Money Laundering Laws in the U.S., CLAIMS Journal (Jan. 8, 2018), https://www.claimsjournal.com/news/national/2018/01/08/282388.htm.

83 Id.

${ }^{84}$ See Sports Wagering Market Integrity Act, S. 3793, 115th Cong. (2018) (hereinafter Sports Wagering Act).

${ }^{85}$ See Jordain Carney, Hatch to Introduce Sports Betting Bill After Supreme Court Decision, THE HiLl (May 14, 2018), https://thehill.com/blogs/floor-action/senate/387594-gop-senator-to-introduce-sports-betting-bill-after-supreme-court
} 
by Senator Mitt Romney. ${ }^{86}$ Although little attention was given to this proposal in 2019, the Romney-Schumer bill shares some of the features of the HatchSchumer initiative. ${ }^{87}$ That bill, ambitiously titled the Sports Wagering Market Integrity Act, is a mixed bag as a model for federal legislation.

The bill creates a National Sports Wagering Clearinghouse, which would be funded by proceeds collected through the federal excise tax on sports betting. ${ }^{88}$ The Clearinghouse would collect and disseminate data on sports wagering, act as a resource center for sports integrity issues, and work with both the private and public markets in sports wagering. ${ }^{89}$ It is at least a starting point for how the federal government could be involved in promoting sports betting integrity.

The Schumer-Romney proposal also would amend the Wire Act to allow for interstate sports wagers pursuant to compacts between states, and it would eliminate any concern about the "intermediate routing" issue. ${ }^{90}$ Though specifics are lacking, there is reference in the bill to toughening up enforcement of illegal sports betting and precluding anyone convicted of violating the Sports Bribery Act from being involved in sports betting. ${ }^{91}$ As with the proposal for a data Clearinghouse, these measures move the regulatory ball forward in a positive direction.

Other parts of the bill suggest the difficulty of developing a focused and limited role for the federal government when a law is drafted. For example, the bill specifies an approval process of state sports wagering systems by the United States Attorney General. ${ }^{92}$ If the bill were ever to gain the attention of Congress, this approval process would be a contentious issue. On the one hand, the law and its implementing regulations might require states simply to demonstrate compliance with a checklist of factors relating to matters such as problem gambling, geo-fencing measures, prohibiting certain people from betting, and restricting betting on contests like high school sports.

If, however, the determination of compliance with the "checklist" by the Attorney General lacks standards or a means of appealing a denial, the measure will draw resolute opposition from states. ${ }^{93}$ It is not difficult to imagine constitutional arguments being raised by the states along the line of their attack on PASPA.

\footnotetext{
${ }^{86}$ David Purdum, NCAA Pushing for Federal Sport Betting Legislation, ESPN (Sept. 10, 2019), https://www.espn.com/chalk/story/_id/27586235/ncaa-pushing-federal-sport-betting-legislation.

${ }^{87}$ See John Holden, Remember the Federal Sports Betting Bill? Apparently It's Still a Thing, Legal Sports ReP. (Sep. 6, 2019), https://www.legalsportsreport.com/35368/federal-sports-betting-bill-official-league-data/.

${ }^{88}$ Sports Wagering Act, supra note 80, § 106(g)(1)(B).

${ }^{89}$ Id. $\S 106(\mathrm{c})$.

${ }^{90}$ Id. $\S 301(1)(\mathrm{A})-(\mathrm{B})$.

${ }^{91}$ See id. $\S 302$.

92 Id. $\S 102(\mathrm{a})(1)$.

93 See Adam Candee, Hatch, Schumer Preparing to Drop Federal Sports Betting Bill in Senate, Legal Sports ReP. (Dec. 19, 2018), https://www.legalsportsreport.com/26901/federal-sports-betting-bill-drop/ (noting proponents of states' rights disapproved of the bill).
} 
Even more indicative of the difficulty of Congress staying out of the deep political weeds in drafting a law is the bill's requirement that sportsbooks "determine the result of a sports wager only with data that is licensed and provided by the applicable sports organization ... or an entity expressly authorized by the applicable sports organization." 94 The "official data" mandate has been one effort by the major sports leagues to monetize sports betting in their favor after the Murphy decision. ${ }^{95}$ So far, three states have included such a requirement in their laws allowing sports betting. ${ }^{96}$

The argument in favor of this requirement, that bettors should be assured bets are settled according to accurately reported data, has been met with an incredulity of sorts by sportsbooks. They make the point that as a matter of self-interest sportsbooks ensure the information they use to score wagers is accurate and timely, as misreported data can be costly to a sportsbook. Moreover, using a single source for data rather than allowing companies in the sports data space to compete to demonstrate the superiority of their product removes a market check on the integrity of the data used. As far as betting integrity is concerned, use of a single data source makes it easier to corrupt the data reporting process. ${ }^{97}$

The "data issue" is an important one and warrants careful attention. This includes whether the data issue should be viewed as part of the core function of the federal government in its role of regulating the integrity of sports betting. However, the debate on sports wagering legislation in the states has loaded the issue with significant political freight and it could be a significant impediment to developing a consensus on the role of the federal government.

While federal laws take precedence over state laws to the contrary, it is a mistake to ignore the fact that states will have a considerable amount of input on any such legislation. For a bill to have a realistic prospect of becoming law, it seems essential to craft a streamlined system where the roles of the two governmental actors are clearly defined, and where the federal government's role is determined with a recognition of the historic authority states have exercised over gambling.

\section{Conclusion}

After PASPA was swept away by the Supreme Court, anyone thinking that sports betting in the US was simply a matter of flipping a switch was badly mistaken. The process of developing a comprehensive regulatory system for sports betting requires a careful assessment of the objectives of such a system and judgments about how the regulatory burdens should be allocated. While Congress has dithered, state after state has established legal, regulated sports betting, and

\footnotetext{
94 Sports Wagering Act, supra note 80, § 103(b)(5)(A)(i).

${ }^{9}$ See Official League Data, LEgAL SPORTs REP., https://www.legalsportsreport.com/official-league-data/ (last updated Feb. 14, 2020).

$96 \mathrm{Id}$.

97 See Matthew Kredell, Official League Data Mandate Faces Opposition At Indiana Sports Betting Hearing, Legal Sports ReP. (Mar 22, 2019), https://www.legalsportsreport.com/30603/ indiana-sports-betting-official-data/
} 
consideration of the role of the federal government in the regulatory landscape of sports betting has for the most part been absent.

As this article has discussed, however, states face structural and resource problems in fulfilling a basic tenet of regulation, namely, to assure that the underlying sporting event is honest. The actions necessary to achieve this objective requires states to undertake a level of national and international cooperation much different than they have previously engaged in. While states have demonstrated their competence in many areas of gambling regulation, sports betting creates unique challenges, some of which call for the involvement of the federal government.

Unfortunately, Congress has achieved few successes that suggest it would be up to the task of developing a measured federal law that did not overreach into aspects of regulation better left to the states. A checkered statutory history, and the current hyper-partisanship in Congress, are not cause for optimism. However, Congressional stalemates can ease so the debate on the role of the federal and state governments in regulating sports betting needs to be conducted now. Also, those seeking to corrupt sports contests are not waiting for the US to formulate effective efforts to thwart their efforts. What is indisputable is this: as more states pass laws legalizing sports betting, political realities will close the window for establishing a hybrid system of state and federal regulation. Once a critical mass of states with sports betting is reached, the opportunity for collaboration will likely be lost.

If that is the case, any future consideration of these issues may be dictated by events. A major sports scandal or other significant breakdown in the public's trust in the honesty of the sporting events underlying the sports wagers could, not unlike the securities markets in the late 1920 s and early $1930 \mathrm{~s}^{98}$, force a restructuring of the state-federal relationship, or even threaten the very survival of sports wagering as a legal industry. It seems far better to engage in this process now in a deliberate manner rather than as a consequence of exigent circumstances.

\footnotetext{
${ }_{98}$ Before the collapse of the United States Stock markets in the late 1920s and early 1930, individual states exercised market controls under what are known as "Blue Sky" laws. State control proved ineffective as the markets overwhelmed inexperience and often deliberately lax state regulators that result in scandals where investors were defrauded. These problems lead to the creation of the Federal Securities and Exchange Commission and primary regulation of the markets at the federal level. See generally,. Elisabeth Keller \& Gregory A. Gehlmann. Introductory comment: A historical introduction to the Securities Act of 1933 and the Securities Exchange Act of 1934, 49 Оніо Sт. LJ 329 (1988).
} 